Pacific Northwest

National Laboratory

Operated by Battelle for the

U.S. Department of Energy

\section{Analysis of Impacts of Adopting the 2006 International Energy Conservation Code for Residential Buildings in Wyoming}

\author{
R.G. Lucas
}

October 2007

Prepared for

U.S. Department of Energy

under Contract DE-AC05-76RL01830 


\section{DISCLAIMER}

This report was prepared as an account of work sponsored by an agency of the United States Government. Neither the United States Government nor any agency thereof, nor Battelle Memorial Institute, nor any of their employees, makes any warranty, express or implied, or assumes any legal liability or responsibility for the accuracy, completeness, or usefulness of any information, apparatus, product, or process disclosed, or represents that its use would not infringe privately owned

rights. Reference herein to any specific commercial product, process, or service by trade name, trademark, manufacturer, or otherwise does not necessarily constitute or imply its endorsement, recommendation, or favoring by the United States Government or any agency thereof, or Battelle Memorial Institute. The views and opinions of authors expressed herein do not necessarily state or reflect those of the United States Government or any agency thereof.

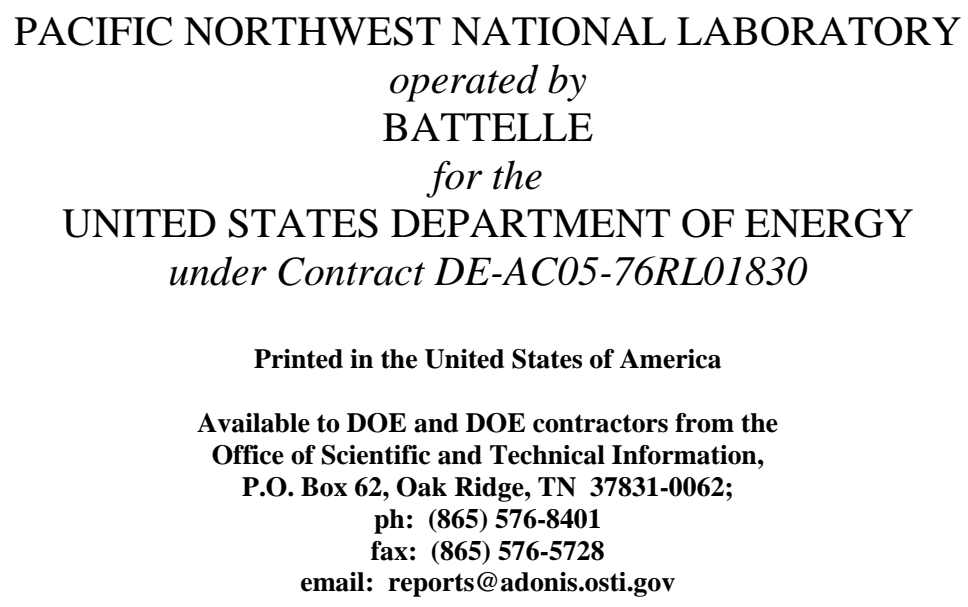

Available to the public from the National Technical Information Service, U.S. Department of Commerce, 5285 Port Royal Rd., Springfield, VA 22161 ph: (800) 553-6847 fax: (703) 605-6900

email: orders@ntis.fedworld.gov online ordering: http://www.ntis.gov/ordering.htm 


\title{
Assessment of Impacts from Adopting the 2006 International Energy Conservation Code for Residential Buildings in Wyoming
}

\author{
R.G. Lucas
}

October 2007

Prepared for

the U.S. Department of Energy under Contract DE-AC05-76RL01830

Pacific Northwest National Laboratory

Richland, Washington 99352 


\section{Summary}

The state of Wyoming currently does not have a statewide building energy efficiency code for residential buildings, although Laramie has adopted the 2003 Edition of the International Code Council's (ICC) International Energy Conservation Code (IECC) (ICC 2003). The U.S. Department of Energy has requested Pacific Northwest National Laboratory (PNNL) to estimate the energy savings and economic impacts from adopting the 2006 IECC. This report addresses the impacts for residential buildings only.

The analysis indicates that homes built to meet the IECC requirements will save Wyoming homeowners money by reducing long-term energy costs by far more than the construction-related cost increases. Homeowners with a typical mortgage should realize a net positive cash flow within 4 years or less in most cases. Construction cost increases and energy savings will vary depending on many factors, including location, fuel prices, house size and characteristics, material and labor costs, and the energy efficiency measures used to comply with the 2006 IECC. 


\section{Contents}

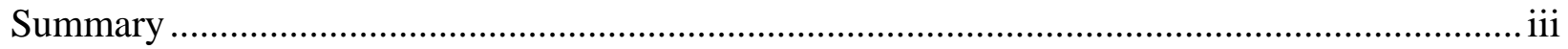

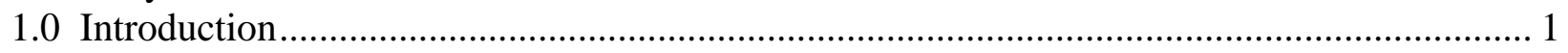

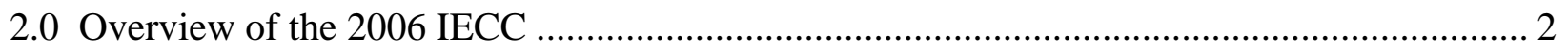

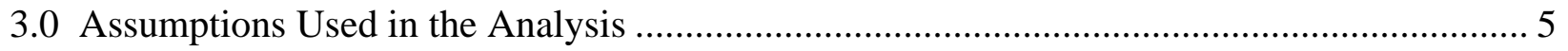

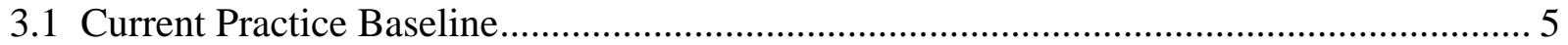

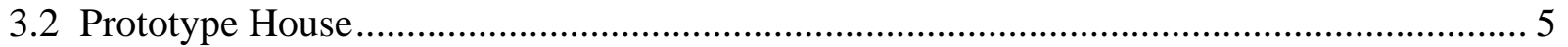

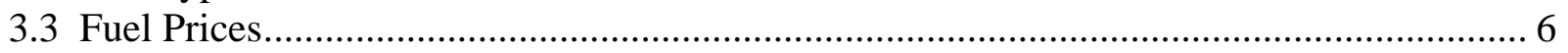

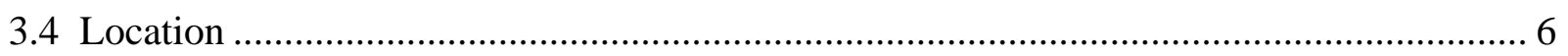

4.0 Impacts from Adopting the 2006 IECC in Wyoming ................................................. 7

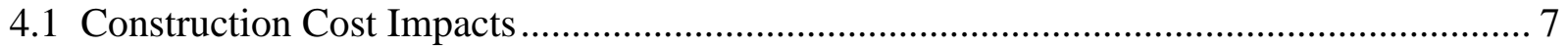

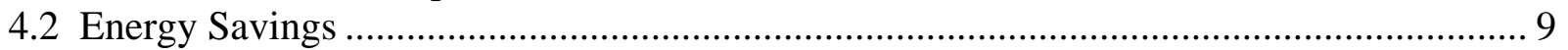

4.3 Economic Impacts Accounting for Mortgages ......................................................... 10

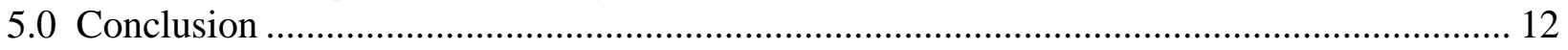

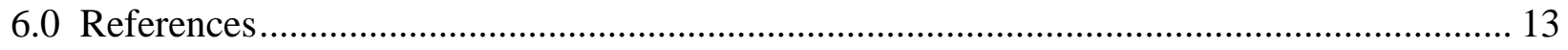

Attachment A - Basement Wall Insulation Options .............................................................. 14 


\section{Figures}

Figure 2. 1. Prescriptive Envelope Requirements in the 2006 IECC................................................ 4

\section{Tables}

Table 4. 1. Example of Trade-offs ............................................................................................ 8

Table 4. 2. Construction Costs (Incremental Relative to Current Practice) for IECC Energy

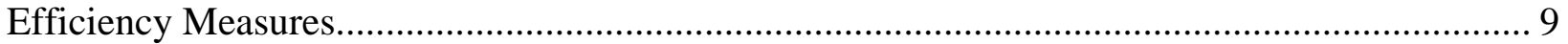

Table 4. 3. Annual Energy Cost and Savings (\$) from Compliance with IECC - Prescriptive Measures

Table 4. 4. Annual Energy Cost and Savings from Compliance with IECC - High Efficiency

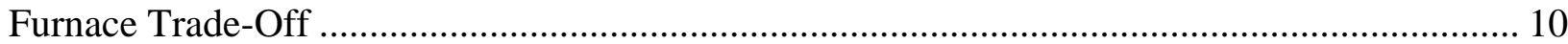

Table 4. 5. Impacts to Consumers' Cash Flow from Compliance with IECC................................. 11 


\subsection{Introduction}

The state of Wyoming currently does not have a statewide building energy efficiency code for residential buildings, although Laramie has adopted the 2003 Edition of the International Code Council's (ICC) International Energy Conservation Code (IECC) (ICC 2003). This report provides estimates of the energy savings and economic impacts from adopting the latest version of the IECC, the 2006 IECC (ICC 2006), for residential buildings.

Section 2 of this report contains an overview of the 2006 IECC. Assumptions used in the analysis are discussed in Section 3. Section 4 discusses the impacts from adopting the 2006 IECC for residential buildings in Wyoming. Section 5 provides conclusions of the analysis, and Section 6 contains a list of publications referenced in this report. 


\subsection{Overview of the 2006 IECC}

The IECC is a nationally recognized model code that contains requirements for the energy efficient design and construction of all building types, in all U.S. locations. Over half of all states have adopted a version of the IECC. Chapter 4 of the IECC contains specific requirements for residential buildings, and Chapters 1 and 2 contain general information applicable to both residential and commercial buildings. The residential building category includes single-family houses, duplexes, and multifamily residential buildings three stories or less above-grade in height. Multifamily buildings include apartments, condominiums, and dormitories, but do not include hotels and motels. Commercial buildings are addressed in Chapter 5 and referenced standards are listed in Chapter 6.

For residential buildings, the IECC addresses energy use from space heating, space cooling, and water heating. Energy savings resulting from the IECC will be from reduced space heating and air conditioning; current construction practice is assumed to comply with the brief requirements in the IECC for water heating.

Perhaps the most significant requirements for residential buildings are the insulation levels for the building envelope. The envelope includes walls, windows and skylights, doors, ceilings, floors, and the perimeter of slab-on-grade foundations. Another requirement for the envelope is that all penetrations and cracks in the building envelope be sealed. These envelope requirements increase as the climate becomes colder. Because Wyoming has very cold winters, the IECC requirements are relatively stringent.

The IECC contains limited requirements for space heating and cooling systems and domestic water heating systems (for showers, sinks, clothes washing, etc.). Efficiency requirements for mechanical equipment (furnaces, boilers, heat pumps, etc.) are set by Federal law and cannot easily be altered by codes at the state or local level. The IECC sets requirements for mechanical system controls, duct sealing and insulation, piping insulation, circulating hot water systems, mechanical ventilation, and equipment sizing. The IECC has important requirements for sealing and insulating ductwork that passes through unconditioned spaces, such as unheated basements and attics.

The IECC contains three alternative compliance paths: simplified prescriptive requirements, a total building envelope UA (U-factor multiplied by area) approach, and a simulated performance approach. The latter two paths allow trade-offs, whereby some building components can fall below code requirements if the energy impact is countered by other components that exceed code requirements. For example, a popular trade-off is to reduce wall insulation and/or other insulation levels if a high-efficiency furnace is used. The IECC allows 
trade-offs as long as the estimated total annual energy cost does not increase. ${ }^{1}$ Several relatively easy-to-use software products are available to assist in designing a building that complies with the IECC, including DOE's free REScheck ${ }^{\mathrm{TM}}$ software (DOE 1995). The IECC has some absolute requirements that can never be traded off, such as sealing ducts and the building envelope and a maximum whole-building average fenestration U-factor of no more than 0.40 $\mathrm{Btu} / \mathrm{hr}-\mathrm{ft}^{2}-\mathrm{F}$.

The 2006 IECC has a simple and clear map-based format for presenting code requirements that vary by climate, where the appropriate climate zone can easily be determined from a county map of the U.S. The 2006 IECC has eight primary climate zones, from hot locations (e.g., southern Florida) to very cold locations (e.g., northern Alaska). Wyoming falls into zones 5, 6, and 7 with most of the state in zone 6 . County borders set climate zone boundaries. To eliminate any doubt about which climate zone applies to a location, a table of climate zones by county is provided in the code. Figure 1 shows the climate zones in Wyoming and the simplified prescriptive envelope requirements for the 2006 IECC. There are some limited exceptions to these prescriptive requirements, including exemptions for $15 \mathrm{ft}^{2}$ of glazing and one door and an allowance for only R-30 insulation for up to $500 \mathrm{ft}^{2}$ of cathedral ceiling, if framing members are too small to accommodate R-38 or R-49.

\footnotetext{
${ }^{1}$ Local jurisdictions may, at their discretion, require that site energy use (Btu) be balanced rather than energy cost.
} 


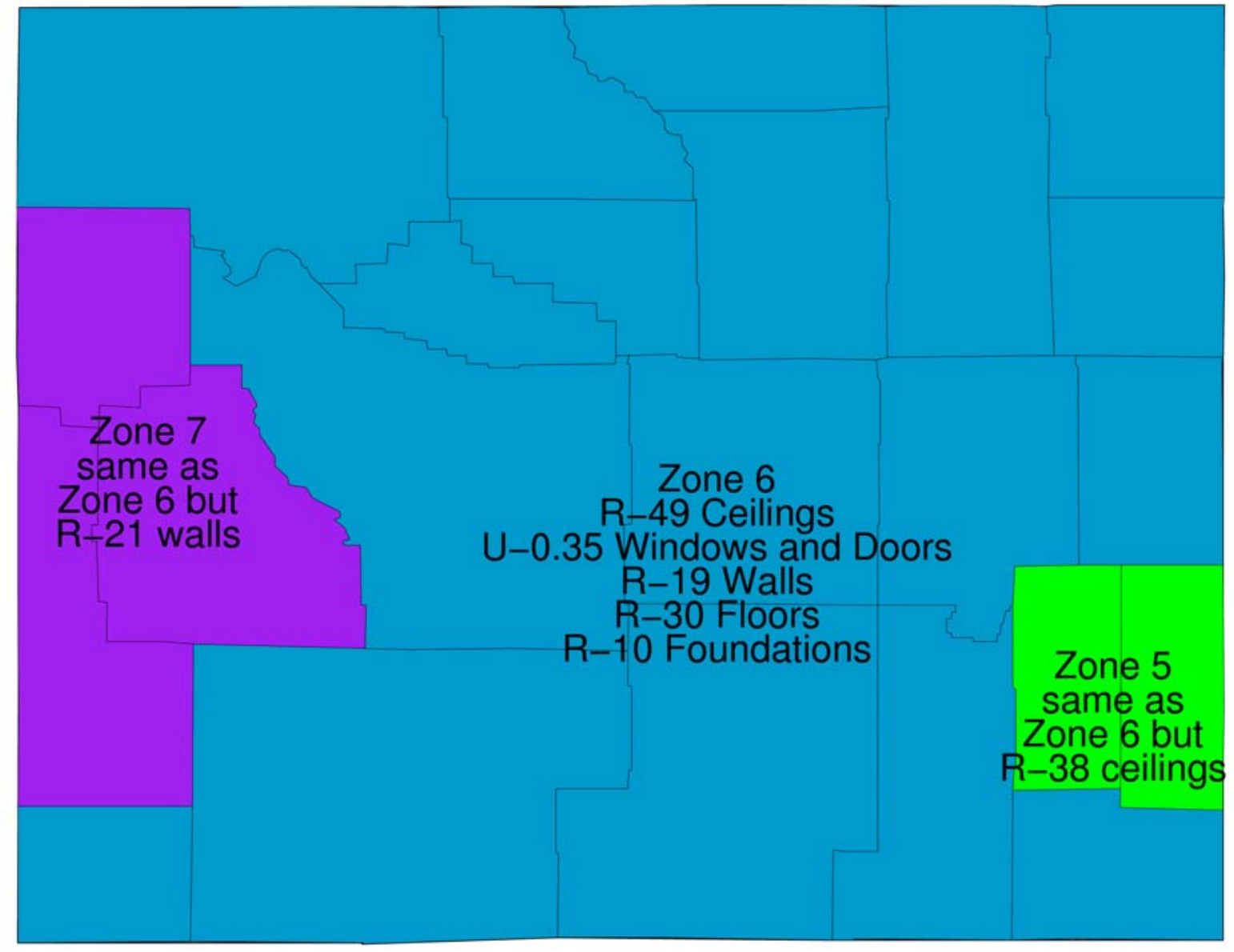

Figure 2.1. Prescriptive Envelope Requirements in the 2006 IECC 


\subsection{Assumptions Used in the Analysis}

\subsection{Current Practice Baseline}

The intent of this analysis is to compare the IECC requirements to current practices for new housing. Although detailed data on current practice within Wyoming was not available for this study, experience with other cold-climate states suggests there is some variation in how energy efficient new buildings are in Wyoming. Some fraction of new construction will fall short of the IECC requirements to varying degrees, some will likely exceed the IECC slightly, and some will just meet the IECC.

State adoption of the IECC will have no impact when current practice already meets the IECC so this report will examine specific construction measures that are most likely to fall short of what the IECC requires for those measures. This report examines wall insulation levels, both basement walls and above-grade walls (the IECC has different requirements for each). The IECC has an R-49 ceiling insulation requirement, while current practice is likely to often be R$38^{2}$. A recent survey suggests that R-38 dominates the market in the Pacific Northwest, including Idaho and Montana, which are adjacent to Wyoming (RLW Analytics 2007).

Other requirements in the IECC are not expected to result in substantial changes. Fenestration requirements in the IECC can be met with low-E glazing. Approximately $80 \%$ of new residential windows nationwide are expected to be low-E in 2008, indicating the cost of this feature is apparently low enough that it is close to becoming standard practice (Architect's Guide to Glass and Metal, January 2007). Low-E windows have an $88.6 \%$ market share in the Pacific Northwest (Washington, Oregon, Idaho, and Montana) based on a survey of 598 houses built in 2004 and 2005, with Montana having 97\% low-E windows (RLW Analytics 2007). Data such as this suggests that low-E windows are likely to already dominate the market in Wyoming. Improved envelope sealing, duct sealing, and duct insulation can save substantial energy, but it is not clear how much impact the code will have for these measures.

\subsection{Prototype House}

The analysis assumes a two-story, 30-ft by 40 -ft single-family house with a conditioned floor area of 2,400 $\mathrm{ft}^{2}$ excluding the heated basement. It was assumed that the house had 8.5-fthigh ceilings, a ceiling area (bordering the unconditioned attic) of $1,200 \mathrm{ft}^{2}$, a gross exterior above-grade wall area of 2,380 $\mathrm{ft}^{2}$, and a basement wall area of $1,120 \mathrm{ft}^{2}$ with the top $1 \mathrm{ft}$. of the basement wall above grade. It was assumed that the house has a total opaque (non-glass) door area of $42 \mathrm{ft}^{2}$ (two doors) and a window area of $357 \mathrm{ft}^{2}$ (15\% of the above-grade wall area).

\footnotetext{
${ }^{2} \mathrm{R}-38$ is also allowed in place of R-49 in the IECC if there is no compression or reduction of insulation height at the eaves of an attic and up to $500 \mathrm{ft}^{2}$ of cathedral ceilings are allowed to have R-30 insulation if there is not space for higher levels.
} 


\subsection{Fuel Prices}

The latest available costs for natural gas and electricity were obtained from the DOE Energy Information Administration (EIA). Natural gas prices have increased dramatically in the past 5 years, and at an average $\$ 9$ per thousand cubic feet (approximately equal to 1 million Btus) in Wyoming for the residential market last winter

(http://tonto.eia.doe.gov/dnav/ng/hist/n3010wy3m.htm). Recent (September 2007) DOE fuel price Short Term Energy Outlook projections estimate residential natural gas prices in the Mountain region (which includes Wyoming) to be modestly higher in next few winters compared to last winter (http://www.eia.doe.gov/emeu/steo/pub/6ctab.html). Based on this, a natural gas cost of $\$ 10 / M B t u$ was assumed in this analysis. The electricity price for air conditioning was assumed to be 8.19 cents/kWh based on Wyoming average residential prices in June 2007 (DOE/EIA http://www.eia.doe.gov/cneaf/electricity/epm/table5_6_a.html).

\subsection{Location}

The climate of Casper is examined in Chapter 4 to give a typical Wyoming climate. Casper is in climate zone 6 of the IECC, which includes most of Wyoming. Detailed weather data necessary for energy simulations for Wyoming locations in zones 5 and 7 is not available. 


\subsection{Impacts from Adopting the 2006 IECC in Wyoming}

The assessment of the impacts from adopting the 2006 IECC for residential buildings in Wyoming includes construction costs impacts, energy savings, mortgage-related cost impacts to consumers, and life-cycle cost impacts.

\subsection{Construction Cost Impacts}

Costs can vary greatly depending on the builder, subcontractors, and materials and equipment suppliers. Costs may decrease after the market adapts to the code requirements and the energy-efficient products required by the code become prevalent. The costs reported here include the builder's profit and represent the sales value of the house.

Costs for above-grade wall insulation increasing from R-13 to R-19 were obtained from R.S. Means (2006) and are $\$ 0.52 / \mathrm{ft}^{2}$ for the increased framing thickness (2-by-4 to 2-by-6) and at most $\$ 0.10 / \mathrm{ft}^{2}$ for the thicker insulation. For ceiling insulation, R.S. Means reports $\$ 0.07 / \mathrm{ft}^{2}$ for the improvement from R-30 to R-38, which is extrapolated to an estimated cost of $\$ 0.10 / \mathrm{ft}^{2}$ for the improvement from R-38 to R-49.

Even when basements are designed to be a heated space, builders are often reluctant to insulate basement walls, and uninsulated basements are assumed for current practice in this analysis. However, if the basement is to be heated, the IECC requires basement wall insulation. There are a variety of methods of insulating basements. The insulation can be either put on the inside of the basement wall (often with fiberglass insulation) or put on the outside of the basement wall with foam sheathing insulation directly in contact with the earth ${ }^{3}$. Insulation on the inside of the basement wall is often covered with drywall but doesn't have to be. Costs of basement insulation can vary considerably based on the technique used. If the basement is "finished" with the walls insulated, framed, wired with outlets, etc., the cost can be several thousands of dollars. Montana has examined methods of basement wall insulation and indicates there are a number of methods with a typical installed cost of \$2000 or less (see Attachment A). A cost of $\$ 2000$ is assumed here. Other methods can cost less. For example, The National Association of Home Builders have estimated a cost of $\$ 990$, although it is not clear exactly what level of insulation this represents (EC42-06/07 Public Comment, http://www.iccsafe.org/cs/codes/2006-07cycle/FAA/IECC.pdf).

One method of obtaining credit towards IECC compliance is the use of high efficiency natural gas furnaces. Builders often find using these types of trade-offs more attractive and presumably a lower cost way of complying with the IECC than the prescriptive approach. This option was examined as an alternative method of complying with the IECC because of the cost

\footnotetext{
${ }^{3}$ The IECC requires foundation insulation exposed to air (at the top of the foundation) to have a protective covering.
} 
effectiveness and popularity of this trade-off. Table 4.1 shows examples of trade-offs calculated using the REScheck ${ }^{\mathrm{TM}}$ 4.1.1 software for the prototype house. A high efficiency furnace allows R-13 above-grade walls. Although difficult, it is also possible to comply with the IECC with uninsulated basement walls for this example house.

Table 4.1. Example of Trade-offs

\begin{tabular}{|l|l|l|}
\hline $\begin{array}{l}\text { Base prescriptive } \\
\text { package }\end{array}$ & $\begin{array}{l}\text { Trade-off option } \\
1\end{array}$ & Trade-off option \\
\hline 78\% efficient & $90 \%$ efficient & 95\% efficient \\
furnace & furnace allowing & furnace, U-0.30 \\
R-49 ceilings & R-13 walls & windows, and U- \\
R-19 walls & & 0.25 doors and \\
U-0.35 windows & & allowing \\
and doors & & uninsulated \\
R-13 basement & & basement walls \\
walls & & \\
& & \\
\hline
\end{tabular}

A 90\% (or higher) annual fuel utilization efficiency (AFUE) condensing natural gas furnace is a substantial improvement in efficiency over a "standard" furnace with an efficiency of about $80 \%$. High efficiency furnaces have gained significant market share in recent years, increasing from 28\% in 2002 to 36.5\% nationwide in 2006 (

http://www.gamanet.org/gama/stats.nsf). High efficiency furnaces are likely to be more common in colder climates. A Wisconsin survey reported that $85 \%$ of furnace sales in 1996 in Wisconsin were at the $90 \%+$ efficiency level (Energy Center of Wisconsin 1997). This same study indicated that the average cost of improving from a standard efficiency furnace to the $90 \%$ efficiency condensing furnace was $\$ 464$. California data gives an incremental equipment cost of $\$ 659$ for an $80 \mathrm{kBtu} / \mathrm{hr} 90 \%$ AFUE gas furnace (Itron 2005).

Table 4.2 summarizes these incremental construction costs for improving energy efficiency measures to meet the 2006 IECC code. In addition to the IECC prescriptive requirements, the trade-off of a high efficiency furnace for a reduction in wall insulation to the R-13 level is considered. Note again that other combinations of improvements in energyefficiency measures can be used to comply with the 2006 IECC and might have a different cost. Actual construction costs related to IECC compliance may vary from those in this report depending on differences in design and construction. As the energy-efficiency measures required by the code gain a larger market share and builders find low-cost methods of meeting the code, it is expected that the first cost impacts of the code will drop. 
Table 4.2. Construction Costs (Incremental Relative to Current Practice) for IECC Energy Efficiency Measures

\begin{tabular}{||l|l|l|}
\hline & $\begin{array}{l}\text { Prescriptive } \\
\text { Package } \\
\text { Option }\end{array}$ & $\begin{array}{l}\text { High Efficiency } \\
\text { Furnace } \\
\text { Option }\end{array}$ \\
\hline Ceiling & $\$ 120$ & $\$ 120$ \\
\hline $\begin{array}{l}\text { Walls } \\
\text { (Above- } \\
\text { grade) }\end{array}$ & $\$ 1228$ & 0 \\
\hline $\begin{array}{l}\text { Basement } \\
\text { Walls }\end{array}$ & $\$ 2000$ & $\$ 2000$ \\
\hline $\begin{array}{l}90 \% \\
\text { Efficient } \\
\text { Gas } \\
\text { Furnace }\end{array}$ & 0 & $\$ 659$ \\
\hline TOTAL & $\$ 3348$ & $\$ 2779$ \\
\hline
\end{tabular}

\subsection{Energy Savings}

The EnergyGauge simulation tool (Florida Solar Energy Center) was used to estimate the energy savings from the building envelope improvements necessary to meet the IECC for the prototype house.

Tables 4.3 shows the annual energy use that will result from complying with the IECC requirements and current practice, and the savings over current practice.

Table 4.3. Annual Energy Cost and Savings (\$) from Compliance with IECC Prescriptive Measures

\begin{tabular}{|l|l|l|l|}
\hline & Heating & \multicolumn{1}{c|}{ Cooling } & \multicolumn{1}{c|}{ Total } \\
\hline IECC & $\$ 1119$ & $\$ 56$ & $\$ 1175$ \\
\hline Current Practice & $\$ 1449$ & $\$ 65$ & $\$ 1514$ \\
\hline Total Savings & $\$ 330$ & $\$ 9$ & $\$ 339$ \\
\hline Percent Savings & $23 \%$ & $14 \%$ & $22 \%$ \\
\hline \hline
\end{tabular}

As described above, the option of complying with the IECC with a $90 \%+$ efficient natural gas furnace and slightly improved windows was also examined. This allows a reduction to R-13 
wall insulation, which is the same as assumed current practice insulation levels in Wyoming. The energy impacts of this IECC compliance option are shown in Table 4.4.

Table 4.4. Annual Energy Cost and Savings from Compliance with IECC - High Efficiency Furnace Trade-Off

\begin{tabular}{|l|l|l|l||}
\hline & Heating & Cooling & Total \\
\hline \hline $\begin{array}{l}\text { IECC (high } \\
\text { furnace efficiency } \\
\text { option) }\end{array}$ & $\$ 1041$ & $\$ 59$ & $\$ 1100$ \\
\hline Current Practice & $\$ 1449$ & $\$ 65$ & $\$ 1514$ \\
\hline Total Savings & $\$ 408$ & $\$ 6$ & $\$ 414$ \\
\hline Percent Savings & $28 \%$ & $9 \%$ & $27 \%$ \\
\hline
\end{tabular}

\subsection{Economic Impacts Accounting for Mortgages}

Because most houses are financed, consumers will be very interested in the financial impacts of buying a home that complies with the 2006 IECC requirements. Mortgages spread the payment for the cost of a house over a long period of time. In this analysis, a fixed-rate mortgage was assumed. It was also assumed that homebuyers will deduct the interest portion of the payments from their income taxes.

The financial and economic parameters required for input to this analysis are summarized below. These parameters are used to calculate the costs and benefits of increased energy efficiency from the homeowner's perspective. A relatively low down payment and a moderate federal income tax rate were selected.

X New-home mortgage parameters:

- $\quad 7.0 \%$ mortgage interest rate (fixed rate)

- $\quad$ points and loan fees equal to $1.6 \%$ of the mortgage amount

- 30-year loan term

- $10 \%$ down payment.

$\mathrm{X}$ Other rates and economic parameters:

- $\quad 7 \%$ nominal discount rate

- $\quad 28 \%$ marginal federal income tax, no state income tax

- $\quad 2 \%$ estimated property tax

- $\quad 3 \%$ nominal inflation for fuel prices

- $\quad 30-$ year analysis period, no residual/salvage value. 
Table 4.5 shows the impacts to consumers' cash flow resulting from IECC compliance. The up-front costs include the down payment, points, and loan fees. The savings from income tax deductions for the mortgage interest will slowly decrease over time. The annual values shown in the table are for the first year. Table 4.5 also includes increases in annual property taxes because of the higher assessed house values. The net annual cash flow includes energy costs, mortgage payments, mortgage tax deductions, and property taxes but not the up-front costs.

Table 4.5. Impacts to Consumers' Cash Flow from Compliance with IECC

\begin{tabular}{|l|l|l|}
\hline & $\begin{array}{c}\text { Prescriptive } \\
\text { Package } \\
\text { Option }\end{array}$ & $\begin{array}{c}\text { High } \\
\text { Efficiency } \\
\text { Furnace } \\
\text { Option }\end{array}$ \\
\hline $\begin{array}{l}\text { Up-Front Costs } \\
\text { (down payment, } \\
\text { etc.) }\end{array}$ & $\$ 376$ & $\$ 312$ \\
\hline $\begin{array}{l}\text { Annual Energy } \\
\text { Savings }\end{array}$ & $\$ 339$ & $\$ 414$ \\
\hline $\begin{array}{l}\text { Annual Mortgage } \\
\text { Increase }\end{array}$ & $\$ 251$ & $\$ 209$ \\
\hline $\begin{array}{l}\text { Annual Income } \\
\text { Tax Deduction } \\
\text { Increase }\end{array}$ & $\$ 62$ & $\$ 51$ \\
\hline $\begin{array}{l}\text { Annual Property } \\
\text { Tax Increase }\end{array}$ & $\$ 49$ & $\$ 41$ \\
\hline $\begin{array}{l}\text { Net Annual Cash } \\
\text { Flow Savings } \\
\text { (excluding up- } \\
\text { front costs) }\end{array}$ & $\$ 101$ & $\$ 215$ \\
\hline $\begin{array}{l}\text { Net Present } \\
\text { Value of Savings }\end{array}$ & $\$ 2249$ & $\$ 4182$ \\
\hline $\begin{array}{l}\text { Time to Net } \\
\text { Positive Cash } \\
\text { Flow }\end{array}$ & $\begin{array}{l}\text { Less than } 4 \\
\text { years }\end{array}$ & $\begin{array}{l}\text { Less than } \\
2 \text { years }\end{array}$ \\
\hline \hline
\end{tabular}




\subsection{Conclusion}

If the IECC were adopted by jurisdictions in the state of Wyoming, or statewide, substantial improvement is expected in the energy efficiency of residential buildings. While the initial cost of construction will rise, energy bills will be substantially reduced. Construction cost increases and energy savings will vary depending on many factors, including location, fuel prices, house size and characteristics, material and labor costs, and the energy-efficiency measures used to comply with the 2006 IECC. The analysis indicates that construction costs for the energy-efficiency measures evaluated in the study would be approximately $\$ 2800$ to $\$ 3300$ in climate zone 6 (most of Wyoming) for a house that would otherwise fall well short of meeting the code.

The analysis concludes that homes built to meet the 2006 IECC requirements will save Wyoming homeowners money by reducing long-term energy costs by far more than the construction-related cost increases. Annual heating and air conditioning cost savings for homes complying with the IECC in Wyoming would be about $\$ 300$ to $\$ 400$ a year for the scenario examined here. Homeowners should generally realize a net positive cash flow in less than 4 years after accounting for the effects of a typical mortgage. For these types of impacts to be achieved, an effort will be required to assist builders and subcontractors in complying with the code, and code officials in enforcing it. 


\subsection{References}

Architect's Guide to Glass and Metal. January 2007.

http://www.usglassmag.com/AGG/BackIssues/2007/GlassTech.htm

Energy Center of Wisconsin. 1997. Forced Air Furnaces and Central Air Conditioner Markets Tracking Sales Through Wisconsin HVAC Contractors. Madison, Wisconsin.

http://www.ecw.org/prod/164-1.pdf

International Code Council (ICC). 2003. 2003 International Energy Conservation Code. Falls Church, Virginia.

International Code Council (ICC). 2006. 2006 International Energy Conservation Code. Falls Church, Virginia.

International Code Council (ICC). 2007. Final Action Agenda. http://www.iccsafe.org/cs/codes/200607cycle/FAA/IECC.pdf

Itron. 2005. 2004/2005 Database for Energy Efficient Resources Update Report.

http://eega.cpuc.ca.gov/deer/

RLW Analytics. 2007. Single-Family Residential New Construction Characteristics and Practices Study. Sonoma, California. http://www.nwalliance.org/research/reports/168.pdf

R. S. Means Company, Inc. (Means). 2006. Means Residential Cost Data--2007, 26th Annual Edition. Kingston, Massachusetts.

U.S. Department of Energy (DOE). 1995. 1995 MECcheck ${ }^{T M}$ Manual, 1992 Model Energy Code Compliance Guide, Version 2.0. Building Standards and Guidelines Program, Pacific Northwest National Laboratory, Richland, Washington.

U.S. Department of Energy, Energy Information Administration (DOE). 2007. Short-Term Energy Outlook, August 8, 2006. Washington, D.C.

http://www.eia.doe.gov/emeu/steo/pub/contents.html 


\section{Attachment A ${ }^{4}$}

September, 2006

\section{For Montana Building Industry Association Newsletter}

\section{Basement Wall Insulation Options}

Have you ever had a homeowner complain about an uncomfortable house or higher than expected utility bills? If it occurred despite a well insulated and sealed home with a basement, their problem is probably caused by uninsulated basement walls.

According to the Building Foundation Design Handbook by Underground Space Center, University of Minnesota, "An uninsulated basement may represent up to $50 \%$ of the heat loss in a tightly-sealed house that is well insulated above grade. It should be noted that insulating foundations not only reduces costs but also results in more comfortable above-grade spaces and, in the case of basements, provides additional habitable space at a low cost.”

The handbook gives energy saving information for both unconditioned basements, and fully conditioned basements that are heated to above 70 degrees. For a 1,500 sq. ft. Montana basement, at the current natural gas price of around \$11 a dekatherm, the estimated annual savings for R-10 interior or exterior insulation compared to no insulation is $\$ 675$ for a conditioned basement, and $\$ 235$ for an unconditioned basement.

One of the reasons basements are not being insulated is installation cost. A 2003 survey of Montana builders found the cost to frame, insulate, wire, and drywall a basement wall was around $\$ 5$ per square foot or about $\$ 6,400$ to insulate and finish a 1,500 sq. ft. basement.

However, the energy savings and added comfort can be achieved without finishing the basement. According to Brad McCall of McCall Development in Billings, it takes two framers about $3 / 4$ of a day to frame the basement walls and an insulator about two hours to install and fire rated cover an R-19 fiberglass blanket. They are building ENERGY STAR houses that require R-19 basement walls. The Montana Energy code requires R-11 insulation when the basement is finished. When it comes time to finish, the cover and insulation are pulled up, wiring is placed behind the framing, and insulation and cover are returned for finishing. Brad says that the cost is around \$2,000 to frame, insulate, and cover a typical $1,400 \mathrm{sq}$. $\mathrm{ft}$. basement. When they explain the benefits to the home buyer, they usually agree to the basement insulation. The small amount that the insulation cost adds to a mortgage payment is easily paid for in energy savings.

John Diem of Advanced Energy Solutions in Missoula installs an R-19 fiberglass insulation blanket reinforced with 18 mil thick vinyl covering for $\$ 1.30$ per square foot. He attaches the blanket at the sill plate, and shoots long anchors with wide washers at 40 inch intervals into the basement wall. For a 1,500 sq. $\mathrm{ft}$. basement, the cost is around $\$ 1,950$. For finishing, a frame wall is built in front of the insulation and electrical is installed; the batts are then cut with long bladed utility knives. The batt remains

\footnotetext{
${ }^{4}$ This attachment courtesy of Paul Tschida of the Montana Department of Environmental Quality.
} 
compressed behind the stud wall, but expands to fill the cavity on either side of the framing.

Leon Chambers of Charter Construction in Missoula reported that it cost around $\$ .75$ per cost square foot to install an R-11 vinyl cover fiberglass blanket in their houses. The insulation blanket is usually installed 60 to 90 days after the basement walls have been poured. Leon is not aware of any moisture problems ever being found behind the blanket when they are removed for finishing the basement. When finishing, the blanket is taken down, cut to fit and placed back into the wall.

The reinforced vinyl covered blanket in R-11 is available from Thermogard in Billings for $\$ .41$ per square foot.

Exterior basement insulation is popular in the Midwest where moist air trapped behind an interior fiberglass walls has caused problems. To prevent the interior condensation and to save energy, one to two inches of foam or dense fiberglass is placed on the exterior of the foundation. Some Midwest contractors are installing external insulation and drainage system for under $\$ 2,000$ on a 1,500 square foot house. Some of the above ground insulation covering materials are; stucco, cement board siding or sheet metal.

Making sure homebuyers are satisfied with their comfort - and energy bills should be worth the extra \$2,000 or less for the insulation of a basement. When the cost and savings information is provided to consumers, many will agree to insulating so they can begin saving on their energy costs. At the current cost of energy, installing insulation will usually pay for itself in less than 8 years and homeowners will enjoy a more comfortable home. For additional information about basement insulation, contact Paul Tschida at the Montana Department of Environmental Quality at 406-841-5232 or ptschida@mt.gov 